al Kimiya, Vol. 2, No. 1, Juni 2015

\title{
IDENTIFIKASI SENYAWA FLAVONOID DARI DAUN KEMBANG Bulan (Tithonia diversifolia) Dengan Metode Pereaksi GESER
}

\author{
Aisyah ZiRCONIA, NunUNG KURNIASIH, DAN VinA AMALIA.* \\ ${ }^{1}$ Jurusan Kimia, Fakultas Sains dan Teknologi, UIN Sunan Gunung Djati Bandung, Jl. A.H. Nasution No. \\ 105 Cipadung, Bandung 40614
}

* email korespondensi: vinaamalia07@ gmail.com

ABSTRAK. Indonesia adalah salah satu negara yang kaya akan jenis flora yang berkhasiat sebagai tanaman obat. Salah satunya yaitu kembang bulan (Tithonia diversifolia). Dari uji yang pernah dilakukan, tanaman ini mengandung senyawa flavonoid yang berguna sebagai anti bakteri dan anti diabetes. Dalam penelitian ini akan ditentukan jenis eluen terbaik untuk mengisolasi senyawa flavonoid dan jenis senyawa flavonoid yang terdapat dalam ekstrak daun kembang bulan. Ekstraksi senyawa flavonoid dari daun kembang bulan dilakukan dengan cara maserasi menggunakan pelarut aseton : air $(7: 3)$ selama $5 \times 24$ jam, kemudian dilakukan fraksinasi menggunakan pelarut $n$-heksana dan etil asetat. Setelah itu, dilakukan uji fitokimia senyawa flavonoid menggunakan uji Wilstatter, Bate-Smith dan $\mathrm{NaOH} 10 \%$. Pemisahan senyawa flavonoid dari ekstrak dilakukan dengan kromatografi lapis tipis (KLT) untuk mencari eluen terbaik dengan variasi eluen yaitu $n$-heksana : etil asetat $(8: 2)$, asam asetat : $\mathrm{H}_{2} \mathrm{O}:$ HCl pekat $(30: 10: 3), n$ butanol : asam asetat : air (4:1:5), dan metanol : etil asetat (4:1), kemudian dilanjutkan dengan isolasi senyawa flavonoid. Identifikasi senyawa flavonoid dilakukan dengan metode pereaksi geser dan FTIR. Hasil penelitian menunjukkan bahwa dari uji fitokimia dari ketiga reagen menunjukkan positif mengandung senyawa flavonoid. Eluen terbaik dalam pemisahan senyawa flavonoid dengan KLT adalah $n$ heksana : etil asetat (8:2) yang dapat digunakan dalam mengisolasi senyawa flavonoid. Eluen ini memisahkan 3 noda dengan warna jingga. Berdasarkan hasil analisis spektrofotometer UV-Vis (metode pereaksi geser), menunjukkan bahwa isolat adalah golongan flavonol. Hasil identifikasi dengan FTIR menunjukkan serapan-serapan yang spesifik dari senyawa flavonoid seperti rentangan asimetri $\mathrm{OH}$ pada bilangan gelombang $3443,9 \mathrm{~cm}^{-1}$, rentangan cincin aromatik pada $11367,9 \mathrm{~cm}^{-1}$, pita serapan kuat karbonil pada angka $1648,3 \mathrm{~cm}^{-1}$ dan golongan eter yang diperkuat oleh puncak serapan $1060,3 \mathrm{~cm}^{-1}$ sehingga senyawa flavonoid yang diduga adalah $5,7,8,3^{\prime}, 4^{\prime}$ pentahidroksiflavonol atau $5,6,7,3^{\prime}, 4^{\prime}$ pentahidroksiflavonol.

Kata kunci: daun kembang bulan (Tithonia diversifolia), flavonoid, kromatografi lapis tipis (KLT), pereaksi geser.

\section{Latar Belakang}

Sebagai negara dengan iklim tropis menjadikan Indonesia kaya akan berbagai macam jenis flora. Sebagian besar flora di Indonesia dapat dimanfaatkan sebagai tanaman obat. Salah satu tanaman yang dapat dijadikan tanaman obat adalah kembang bulan (Tithonia diversifolia). Tanaman kembang bulan berkhasiat sebagai obat diabetes, malaria dan penyakit infeksi lain. Pada penelitian sebelumnya, berdasarkan hasil pemeriksaan skrining fitokimia ekstrak daun kembang bulan menunjukkan hasil bahwa kaya akan kandungan senyawa kimia golongan alkaloid, tanin, dan flavonoid. Selain itu juga ditemukan 14 golongan flavonoid, dan gula pada daun kembang bulan. ${ }^{[1]}$

Isolasi senyawa aktif flavonoid dari tanaman kembang bulan dengan menggunakan berbagai pelarut telah banyak dilakukan. Ratih Pratiwi S menggunakan ekstrak dengan fraksi $n$-butanol untuk melarutkan batu ginjal kalsium secara in-vitro karena diduga adanya kandungan senyawa flavonoid. ${ }^{[2]}$ R. Siregar menggunakan ekstrak etanol daun kembang bulan untuk uji aktivitas antibakteri terhadap bakteri Staphylococcus aureus, Propionibacterium acnes dan Pseudomonas aeruginosa. ${ }^{[3]}$ M. Widari juga telah berhasil mengidentifikasi senyawa flavonoid dari daun kembang bulan yang mengarah pada 5,7,3',4' tetrahidroksiflavon atau luteolin. ${ }^{[4]}$ 
Senyawa flavonoid dilihat dari strukturnya memiliki dua cincin aromatik yang diikat oleh tiga atom karbon yang dapat membentuk cincin ketiga. Kedudukan gugus hidroksil fenol bebas pada inti flavonoid dapat ditentukan dengan menambahkan pereaksi geser ke dalam larutan cuplikan dan mengamati pergeseran puncak serapan yang terjadi. Dengan demikian, secara tak langsung cara ini berguna untuk menentukan kedudukan gula atau metal yang terikat pada salah satu gugus hidroksil fenol. Keuntungan utama cara ini adalah sedikitnya jumlah sampel yang diperlukan untuk analisis lengkap.

Pada penelitian ini, senyawa flavonoid diekstraksi menggunakan metode maserasi. Ekstrak yang didapat dilakukan uji fitokimia dilanjutkan pemisahan senyawa flavonoid menggunakan kromatografi lapis tipis dan identifikasi menggunakan metode pereaksi geser. Penelitian ini bertujuan untuk menganalisis jenis eluen terbaik dan jenis senyawa flavonoid dari ekstrak daun kembang bulan.

\section{Metode Penelitian}

\section{Bahan}

Bahan utama yang digunakan dalam penelitian ini adalah daun kembang bulan yang tumbuh di sekitar SMPN 46 Bandung. Bahanbahan yang digunakan meliputi aseton redestilasi, $n$-heksana teknis, n-heksana redestilasi, etil asetat redestilasi, akuades, asam askorbat $10 \mathrm{mM}$, gelatin, formaldehid $3 \%$, serbuk magnesium teknis, $\mathrm{HCl}$ pekat teknis, $\mathrm{NaOH} \mathrm{10 \%} \mathrm{(teknis),} \mathrm{asam} \mathrm{sulfat} \mathrm{pekat} \mathrm{teknis,}$ pereaksi wagner, serbuk natrium asetat p.a, $\mathrm{HCl}$ pekat p.a, $\mathrm{FeCl}_{3} 1 \%$ teknis, asam sulfat dalam etanol, asam asetat teknis, n-butanol teknis, metanol teknis, $\mathrm{NaOH} 2 \mathrm{M}$ p.a, $\mathrm{AlCl}_{3} 5 \%$ dalam methanol p.a, $\mathrm{AlCl}_{3} 1 \%$ teknis, dan $\mathrm{H}_{3} \mathrm{BO}_{3}$ p.a.

\section{Peralatan}

Alat penelitian yang digunakan pada penelitian ini meliputi beaker glass dengan berbagai ukuran, gelas ukur dengan berbagai ukuran, corong pisah, labu ukur $100 \mathrm{~mL}$, gelas arloji, timbangan mettler, vacuum rotary evaporator, pengaduk kaca, waterbath, kertas saring, pipa kapiler, plat KLT silika $\mathrm{G}_{60} \mathrm{~F}_{254}$, bejana pengembang, tabung reaksi, kertas saring, pipet tetes, seperangkat alat spektrofotometer UV-Vis, dan seperangkat alat spektrofotometer FTIR.

\section{Cara Kerja}

\section{a. Preparasi sampel}

Daun kembang bulan yang muda dicuci bersih dengan air kemudian diangin-anginkan hingga benar-benar kering dan mudah dipatahkan, kemudian diblender sampai diperoleh serbuk. Hasil yang diperoleh kemudian digunakan sebagai sampel penelitian. b. Ekstraksi

Serbuk daun kembang bulan ditimbang sebanyak 200 gram kemudian direndam dengan $1600 \mathrm{~mL}$ pelarut aseton : air (7:3) dengan penambahan $12 \mathrm{~mL}$ asam askorbat $10 \mathrm{mM}$. Ekstrak kasar daun kembang bulan dipekatkan dengan menggunakan vacuum rotary evaporator dan pemanasan di atas waterbath pada suhu $40-50{ }^{\circ} \mathrm{C}$

\section{c. Fraksinasi}

Cairan hasil ekstrak dipartisi dengan $n$ heksana $(3 \times 25 \mathrm{~mL})$ menggunakan corong pisah sehingga terbentuk 2 lapisan. Lapisan $n$ heksana dipisahkan dan lapisan air 1 dipartisi dengan etil asetat $(3 \times 25 \mathrm{~mL})$ dan terbentuk 2 lapisan. Lapisan organik (etil asetat) dipisahkan dan lapisan air dipekatkan dengan vacuum rotary evaporator.

\section{d. Uji Fitokimia Senyawa Metabolit}

1) Uji Fitokimia Flavonoid

Ketiga fraksi masing- masing dimasukkan ke dalam 3 tabung reaksi masingmasing sebanyak $1 \mathrm{~mL}$. Ekstrak pada tabung pertama direaksikan dengan serbuk magnesium dan 2-4 tetes $\mathrm{HCl}$ pekat. Kemudian campuran dikocok. Terbentuknya warna merah menunjukkan adanya flavonoid golongan flavonol dan flavanon. Pada tabung kedua ditambahkan dengan $\mathrm{HCl}$ pekat beberapa tetes. Kemudian campuran dipanaskan selama 15 menit di atas penangas. Terbentuknya warna jingga menunjukkan adanya flavonoid golongan antosianidin. Pada tabung ketiga ditambahkan larutan $\mathrm{NaOH} 10 \%$ beberapa tetes. Terjadinya perubahan warna menunjukkan adanya flavonoid karena tergolong senyawa fenol.

2) Uji Fitokimia Tanin 
Ketiga fraksi masing- masing dimasukkan ke dalam 3 tabung reaksi masingmasing sebanyak $3 \mathrm{~mL}$. Ekstrak pada tabung pertama direaksikan dengan 3 tetes larutan $\mathrm{FeCl}_{3} 1 \%$. Jika ekstrak mengandung senyawa tanin akan menghasilkan warna hijau kehitaman atau biru tua. Pada tabung kedua ditambahkan dengan larutan gelatin jika terbentuk endapan putih maka positif mengandung tanin. Pada tabung ketiga digunakan untuk membedakan tanin katekol dan galat dengan cara menambahkan ekstrak dengan formadehid $3 \%$ : asam klorida (2:1) dan dipanaskan dalam air panas dengan suhu $90^{\circ} \mathrm{C}$ jika terbentuk endapan merah muda merupakan tanin katekol. Filtrat dipisahkan dengan disaring dan dijenuhkan dengan Na-Asetat dan ditambahkan $\mathrm{FeCl}_{3} 1 \%$ adanya tanin galat ditunjukkan dengan terbentuknya warna biru tinta atau hitam.

3) Uji Fitokimia Alkaloid

Sebanyak 1-2 mL ekstrak dimasukkan ke dalam tabung reaksi lalu ditambahkan dengan $2 \mathrm{~mL}$ kloroform. Campuran ditambahkan dengan $2 \mathrm{~mL}$ amoniak, dikocok dan disaring. Filtrat yang dihasilkan kemudian ditambahkan dengan asam sulfat pekat sebanyak 3-5 tetes dan dikocok sampai terbentuk 2 lapisan. Lapisan asam yang tidak berwarna ditambahkan dengan pereaksi wagner sebanyak 4-5 tetes. Adanya alkaloid ditandai dengan terbentuknya endapan coklat merah setelah penambahan pereaksi wagner.

\section{e. Pemisahan Senyawa Flavonoid}

Pada pemisahan dengan KLT analitik digunakan plat silika $\mathrm{G}_{60} \mathrm{~F}_{254}$ yang sudah diaktifkan dengan pemanasan dalam oven pada suhu $100{ }^{\circ} \mathrm{C}$ selama 10 menit. Masing-masing plat dengan ukuran $5 \mathrm{~cm} \times 10 \mathrm{~cm}$. Dari setiap fraksi ditotolkan pada jarak $1 \mathrm{~cm}$ dari tepi bawah plat dengan pipa kapiler kemudian dikeringkan dan dielusi dengan fase gerak $n$ heksana : etil asetat (8:2) dengan pendeteksi asam sulfat dalam etanol, forestal (asam asetat $: \mathrm{H}_{2} \mathrm{O}: \mathrm{HCl}$ pekat) (30:10:3), $n$-butanol : asam asetat : air (4:1:5), dan metanol : etil asetat (4:1) dengan pendeteksi $\mathrm{AlCl}_{3} 1 \%$. Setelah gerakan larutan pengembang sampai pada garis batas, elusi dihentikan, selanjutnya dengan memerhatikan bentuk noda pada berbagai larutan pengembang ditentukan perbandingan larutan pengembang yang paling baik untuk keperluan preparatif. Noda yang terbentuk diperiksa dengan lampu UV-Vis pada panjang gelombang $254 \mathrm{~nm}$ dan $366 \mathrm{~nm}$.

Pada pemisahan dengan KLT preparatif digunakan plat silika $\mathrm{G}_{60} \mathrm{~F}_{254}$ dengan ukuran 10 $\mathrm{cm}$ x $20 \mathrm{~cm}$. Fraksi yang paling baik hasilnya dari KLT analitik, kemudian ditotolkan sepanjang plat pada jarak $1 \mathrm{~cm}$ dari garis bawah dan $1 \mathrm{~cm}$ dari garis tepi. Selanjutnya dielusi dengan menggunakan eluen yang memberikan pemisahan terbaik pada KLT analitik. Setelah gerakan larutan pengembang sampai pada garis batas, elusi dihentikan. Noda-noda diperiksa di bawah sinar UV pada panjang gelombang 254 $\mathrm{nm}$ dan $366 \mathrm{~nm}$.

\section{f. Identifikasi Senyawa Flavonoid}

Isolat-isolat yang diperoleh dari hasil KLT preparatif, dilarutkan dengan aseton : air dan disentrifugasi kemudian dianalisis dengan spektrofotometer UV-Vis. Masing-masing isolat sebanyak $2 \mathrm{~mL}$ dimasukkan dalam kuvet dan diamati spektrumnya pada bilangan gelombang 200-800 nm. Identifikasi dilanjutkan dengan penambahan pereaksi geser $\mathrm{NaOH} 2 \mathrm{M}, \mathrm{AlCl}_{3} 5 \%, \mathrm{CH}_{3} \mathrm{COONa}$, $\mathrm{CH}_{3} \mathrm{COONa} / \mathrm{H}_{3} \mathrm{BO}_{3}$. Kemudian diamati pergeseran puncak serapannya. Tahapan kerja penggunaan pereaksi geser adalah sebagai berikut:

a. Isolat yang dapat diamati pada panjang gelombang 200-800 nm, direkam dan dicatat spektrum yang dihasilkan.

b. Isolat dari tahap 1 ditambah 3 tetes $\mathrm{NaOH} 2$ $\mathrm{M}$ kemudian dikocok hingga homogen dan diamati spektrum yang dihasilkan.

c. Isolat dari tahap 1 kemudian ditambah 6 tetes pereaksi $\mathrm{AlCl}_{3} 5 \%$ dalam metanol kemudian dicampur hingga homogen dan diamati spektrumnya.

d. Isolat dari tahap 1 ditambah serbuk natrium asetat kurang lebih $250 \mathrm{mg}$. Campuran dikocok sampai homogen menggunakan vortex dan diamati lagi spektrumnya. Selanjutnya larutan ini ditambah asam borat kurang lebih $150 \mathrm{mg}$ dikocok sampai homogen dan diamati spektrumnya.

Isolat hasil KLT preparatif yang diduga senyawa flavonoid diidentifikasi dengan menggunakan spektrofotometer FTIR. 0,2 g pelet $\mathrm{KBr}$ ditambahkan dengan satu tetes isolat 
yang diduga senyawa flavonoid, dikeringkan kemudian diidentifikasi dengan spektrofotometer FTIR dengan panjang gelombang $4000-400 \mathrm{~cm}^{-1}$

\section{Hasil dan Pembahasan}

\section{Ekstraksi}

Serbuk daun kembang bulan yang telah dipreparasi sebelumnya, diekstraksi dengan metode maserasi. Karena senyawa polifenol terutama flavonoid dalam daun kembang bulan rentan terhadap panas yakni pada suhu di atas $60{ }^{\circ} \mathrm{C}$. ${ }^{\circ} \mathrm{C}$. Perbandingan untuk melakukan maserasi ini sebesar 1:8, yaitu 200 g simplisia yang telah digiling dilarutkan ke dalam 1,6 liter pelarut aseton-air (7:3) dengan penambahan 12 $\mathrm{mL}$ asam askorbat bertujuan sebagai antioksidan, sehingga tidak terjadi oksidasi pada senyawa flavonoid yang mudah teroksidasi pada saat proses ekstraksi. Ekstraksi maserasi ini dilakukan dengan dalam pelarut aseton-air (7:3), pemilihan pelarut ini didasarkan atas percobaan sebelumnya yang dilakukan oleh markham yaitu aseton dapat melarutkan senyawa flavonoid dan dengan adanya gula yang terikat pada flavonoid cenderung menyebabkan flavonoid lebih mudah larut dalam air dan dengan demikian campuran aseton dan air lebih baik untuk flavonoid terikat dengan glikosida. ${ }^{[7]}$

Setelah dalam waktu 5 hari didapat ekstrak kasar sebanyak 8 liter kemudian ekstrak tersebut dipekatkan dengan vacuum evaporatory pada suhu $40^{\circ} \mathrm{C}-50^{\circ} \mathrm{C}$. Pada suhu $40^{\circ} \mathrm{C}-50^{\circ} \mathrm{C}$ senyawa dapat terpisah dari pelarutnya dan senyawa flavonoid yang ingin dianalisis tak teroksidasi. Vacuum dalam rotary evaporator berfungsi untuk mempermudah proses penguapan pelarut dengan memperkecil tekanan dalam vacuum dari pada di luar ruangan, sehingga temperatur di bawah titik didih pelarut dapat menguap dan didapat hasil ekstrak aseton sebesar 24 gram. Nilai rendemen ekstrak daun kembang bulan sebesar $12 \%$ (b/b) atau sama dengan 24 gram dari 200 gram serbuk daun kembang bulan. Hasil ekstrak berupa pasta coklat. Hasil ekstrak kemudian dilakukan uji fraksinasi dan uji fitokimia sebelum dilakukan pemisahan dan identifikasi senyawa flavonoid.

\section{Fraksinasi}

Fraksinasi bertujuan untuk memisahkan senyawa berdasarkan perbedaan kepolaran dalam suatu tanaman sehingga jumlah dan jenisnya menjadi fraksi berbeda. Ekstrak kental aseton difraksinasi menggunakan $n$-heksana dan etil asetat untuk memisahkan senyawa berdasarkan perbedaan kepolaran dalam suatu tanaman sehingga jumlah dan jenisnya menjadi fraksi berbeda. Mula-mula ekstrak difraksinasi dengan pelarut yang non polar ( $n$-heksana), kemudian difraksinasi dengan pelarut yang kurang polar (etil asetat) dan terakhir dengan pelarut polar. Dengan menggunakan metode fraksinasi diharapkan selektivitas dari pelarut dalam menarik komponen bahan aktif sesuai dengan kepolarannya. Dengan menggunakan metode fraksinasi diharapkan selektivitas dari pelarut dalam menarik komponen bahan aktif sesuai dengan kepolarannya.

Hasil ekstrak dari masing-masing pelarut dapat dilihat pada Tabel 1.

\section{Analisis fitokimia}

Ekstrak yang telah di partisi yaitu fraksi n-heksana, etil asetat dan aseton diuji kandungan senyawanya secara kualitatif dengan menggunakan uji fitokimia. Pengujian fitokimia ini meliputi uji flavonoid, uji tanin, dan uji alkaloid.

Pada uji flavonoid yang pertama yaitu Uji Wilstatter. Pada uji ini, polihidroksi dari flavonol akan direduksi oleh logam magnesium dalam asam klorida dalam larutan etanol sehingga membentuk garam benzopirilium atau flavilium yang berwarna merah dan terbentuknya buih. Uji flavonoid yang kedua yaitu Uji Bate-Smith, $\mathrm{HCl}$ akan menghidrolisis dan memecahkan antosianin menjadi aglikonnya yaitu antosianidin dan dengan adanya pemanasan akan mempercepat reaksi tersebut hingga terbentuk warna jingga. Uji flavonoid yang ketiga adalah uji $\mathrm{NaOH} 10 \%$. Senyawa flavonoid akan membentuk

Tabel 1 Hasil ekstrak berbagai fraksi

\begin{tabular}{|c|c|}
\hline Fraksi & Ekstrak kental $(\mathrm{g})$ \\
\hline$n$-heksana & $2,4 \mathrm{~g}$ \\
\hline Etil Asetat & $3 \mathrm{~g}$ \\
\hline Aseton & $10,2 \mathrm{~g}$ \\
\hline
\end{tabular}


asetofenon yang berwarna merah hingga coklat bila direaksikan dengan $\mathrm{NaOH}$. Adapun hasil uji fitokimia ekstrak daun kembang bulan berbagai fraksi dapat dilihat pada Tabel 2.

Dari hasil yang diperoleh ternyata yang menunjukkan hasil positif dari ketiga uji di atas adalah fraksi aseton dan etil asetat. Hal ini sesuai bahwa senyawa flavonoid dapat larut dalam pelarut polar seperti metanol, etanol, etil asetat atau pelarut polar lainnya. ${ }^{[5]}$ Senyawa yang terkandung dalam ekstrak fraksi $n$ heksana yaitu tanin. Senyawa yang terkandung dalam ekstrak fraksi etil asetat yaitu flavonoid, dan tanin. Hal ini menunjukkan bahwa senyawa tersebut bersifat semipolar karena larut dalam pelarut yang bersifat semipolar. Sedangkan untuk senyawa yang terkandung dalam ekstrak fraksi aseton yaitu flavonoid, tanin dan alkaloid. Hal ini menunjukkan bahwa semua senyawa tersebut bersifat polar karena larut dalam pelarut yang bersifat polar.

\section{Pemisahan senyawa flavonoid}

Pemisahan senyawa flavonoid dilakukan dengan metode kromatografi lapis tipis (KLT). Plat KLT silika $\mathrm{G}_{60} \mathrm{~F}_{254}$ diaktivasi pada suhu $100{ }^{\circ} \mathrm{C}$ selama 10 menit untuk menghilangkan air yang terdapat pada plat. ${ }^{[9]} \mathrm{KLT}$ analitik ini digunakan untuk mencari eluen terbaik dari beberapa eluen yang baik dalam pemisahan senyawa flavonoid.

Eluen yang baik adalah eluen yang bisa memisahkan senyawa dalam jumlah yang banyak ditandai dengan munculnya noda. Noda yang terbentuk tidak berekor dan jarak antara noda satu dengan yang lainnya jelas. ${ }^{[8]}$ Pemisahan senyawa flavonoid dengan KLT menggunakan beberapa eluen campuran $n$ heksana : etil asetat (3:2) dengan pendeteksi 10 $\% \mathrm{H}_{2} \mathrm{SO}_{4}$ dalam etanol, asam asetat : $\mathrm{H}_{2} \mathrm{O}: \mathrm{HCl}$ pekat (forestal) (30:10:3), $n$-butanol : asam asetat : air (4:1:5), dan metanol : etil asetat (4:1) dengan pendeteksi $\mathrm{AlCl}_{3} 1 \%$. Adapun data penampakan noda dari ketiga fraksi hasil KLT analitik dengan beberapa eluen menggunakan lampu UV $254 \mathrm{~nm}$ dan $366 \mathrm{~nm}$ tersaji pada

\section{Tabel 3.}

Dari beberapa eluen hanya campuran $n$ heksana-etil asetat yang dapat terpisah dengan baik. Ini menunjukan campuran $n$-heksana : etil asetat (8:2) dengan pendeteksi asam sulfat dalam etanol yang dinilai baik dalam memisahkan senyawa flavonoid yang artinya adanya kedekatan kepolaran antara senyawa flavonoid dengan eluen maka senyawa flavonoid semakin terbawa oleh fasa gerak. Adanya flavonoid ditunjukkan dari warna noda saat disinari dengan lampu UV 366 berwarna jingga. Menurut markham bahwa flavonoid golongan flavonol dapat dideteksi dengan sinar UV pendek berupa noda yang berwarna jingga. ${ }^{[7]}$ Adapun data penampakan noda dari ketiga fraksi hasil KLT analitik dengan eluen terbaik campuran $n$-heksana : etil asetat $(8: 2)$ menggunakan lampu UV $254 \mathrm{~nm}$ dan $366 \mathrm{~nm}$ disajikan pada Tabel 4.

Tabel 2 Hasil uji fitokimia ekstrak daun kembang bulan berbagai fraksi

\begin{tabular}{|l|c|c|c|}
\hline \multicolumn{1}{|c}{ Uji } & \multicolumn{3}{|c|}{ Ekstrak } \\
\cline { 2 - 4 } & Fraksi $n$-heksana & Fraksi Etil Asetat & Fraksi Aseton \\
\hline Uji Flavonoid : & & & + \\
d. Uji Wilstatter & - & + & + \\
e. Uji Bate-Smith & - & + & + \\
f. Uji NaOH 10\% & - & + & + \\
\hline Uji Tanin & + & + & + \\
\hline Uji Alkaloid & - & + & + \\
\hline
\end{tabular}

Tabel 3. Penampakan noda dari ketiga fraksi hasil KLT analitik dengan beberapa eluen.

\begin{tabular}{|r|c|c|}
\hline Eluen & Jumlah noda & Keterangan \\
\hline$n$-butanol : Asam Asetat : Air (BAA) $(4: 1: 5)$ & - & Tak terpisah \\
\hline Asam Asetat : Air : HCl Pekat $(30: 10: 3)$ & - & Tak terpisah \\
\hline Metanol : Etil Asetat $(4: 1)$ & - & Tak terpisah \\
\hline$n$-heksana: Etil Asetat $(8: 2)$ & 3 & Terpisah baik \\
\hline
\end{tabular}


Hasil pemisahan senyawa flavonoid dengan KLT analitik pada Tabel 4 menunjukkan bahwa fraksi etil asetat dan aseton mengandung flavonoid. Kandungan flavonoid tertinggi terdapat dalam fraksi etil asetat. Oleh karena itu, fraksi etil asetat yang digunakan dalam isolasi flavonoid menggunakan KLT preparatif. Noda-noda hasil KLT preparatif yang memiliki warna yang menunjukkan flavonoid dikerok dan dilarutkan dalam pelarut aseton: air (7:3) agar senyawa yang telah dikerok dapat terpisah dari silika KLT preparatif dengan cara disentrifugasi.

\section{Identifikasi Pemisahan Senyawa Flavonoid}

Dari strukturnya flavonoid mengandung sistem aromatik yang terkonjugasi sehingga menunjukkan pita serapan kuat pada daerah spektrum UV dan spektrum tampak. Penentuan spektrum menggunakan spektrofotometer UVVis dengan penambahan pereaksi geser $\mathrm{NaOH}$ $2 \mathrm{M}, \mathrm{AlCl}_{3} 5 \%, \quad \mathrm{CH}_{3} \mathrm{COONa}$, $\mathrm{CH}_{3} \mathrm{COONa} / \mathrm{H}_{3} \mathrm{BO}_{3}$.

Dari data spektrum penambahan isolat dengan pelarut metanol, maka isolat yang diduga senyawa flavonoid memiliki panjang gelombang pada pita I sebesar $365 \mathrm{~nm}$ dan pita
II sebesar $280 \mathrm{~nm}$. Hal ini didukung dengan hasil rentangan serapan spektrum UV-Vis flavonol (flavonoid terkondensasi) yakni pada rentang pita I antara 350-385 dan pita II antara 250-280 nm. Adapun data spektrum UV-Vis dari isolat flavonoid sebelum dan sesudah penambahan pereaksi geser dapat dilihat pada

\section{Tabel 5.}

Dari data spektrum penambahan isolat dengan pelarut metanol, maka isolat yang diduga senyawa flavonoid memiliki panjang gelombang pada pita I sebesar $365 \mathrm{~nm}$ dan pita II sebesar $280 \mathrm{~nm}$. Hal ini didukung dengan hasil rentangan serapan spektrum UV-Vis flavonol (flavonoid terkondensasi) yakni pada rentang pita I antara 350-385 dan pita II antara 250-280 nm.

Untuk mengetahui kedudukan gugus fenol dapat ditentukan dengan pereaksi geser. Penambahan $\mathrm{NaOH} 2 \mathrm{M}$ menyebabkan pergeseran batokhromik mengarah ke arah kiri sebesar $15 \mathrm{~nm}$, yakni pada pita I sebesar $10 \mathrm{~nm}$ dan pita II sebesar $5 \mathrm{~nm}$ dan terjadinya penurunan kekuatan serapan. Hal ini menunjukkan bahwa isolat yang mengandung flavonoid dimana hidroksilasi pada cincin A akan berpengaruh pada serapan pita II

Tabel 4. Penampakan noda dari ketiga fraksi hasil KLT analitik $n$-heksana : etil asetat (8:2).

\begin{tabular}{|c|c|}
\hline Fraksi & Noda \\
\hline$n$-heksana & Tidak ada \\
\hline Etil asetat & +++ \\
\hline Aseton & ++ \\
\hline
\end{tabular}

Tabel 5. Data spektrum UV-Vis dari isolat isolat flavonoid sebelum dan sesudah penambahan pereaksi geser.

\begin{tabular}{|c|c|c|c|c|c|}
\hline \multirow[t]{2}{*}{ Perlakuan } & \multicolumn{2}{|c|}{$\begin{array}{c}\text { Panjang } \\
\text { Gelombang } \\
(\mathrm{nm})\end{array}$} & \multicolumn{2}{|c|}{ Pergeseran } & \multirow[t]{2}{*}{ Keterangan } \\
\hline & Pita I & Pita II & Pita I & Pita II & \\
\hline Isolat $+\mathrm{CH}_{3} \mathrm{OH}$ & 365 & 280 & tetap & tetap & $\begin{array}{l}\text { Flavonol (OH bebas pada } \\
\text { karbon nomor } 3 \text { cincin } \mathrm{C})\end{array}$ \\
\hline Isolat $+\mathrm{NaOH}$ & 355 & 275 & -10 & -5 & $\begin{array}{l}\text { 3,4'-OH, } o \text { - diOH pada cincin } \\
\text { A; pada cincin } \mathrm{B}: 3 \mathrm{OH} \\
\text { berdampingan }\end{array}$ \\
\hline Isolat $+\mathrm{AlCl}_{3} 5 \%$ & 410 & 275 & +45 & -5 & $\begin{array}{l}o-\text { diOH pada cincin } \mathrm{B} \text {, adanya } \\
5-\mathrm{OH}\end{array}$ \\
\hline Isolat $+\mathrm{CH}_{3} \mathrm{COONa}$ & 385 & 280 & +20 & tetap & $7-\mathrm{OH}$ \\
\hline $\begin{array}{c}\text { Isolat }+ \\
\mathrm{CH}_{3} \mathrm{COONa} / \mathrm{H}_{3} \mathrm{BO}_{3} \\
\end{array}$ & 365 & 275 & tetap & -5 & $\begin{array}{l}o \text { - diOH pada cincin A }(6,7 \\
\text { atau } 7,8)\end{array}$ \\
\hline
\end{tabular}


sedangkan hidroksilasi pada cincin B akan berpengaruh pada serapan pita I. ${ }^{[8]}$

Pada struktur inti flavonoid, terdapat gugus hidroksil pada posisi karbon nomor 4 dan karbon nomor 3 pada cincin B berdampingan dan bentuk $o$-diOH (orto-dihidroksi) pada cincin A, sehingga dapat dikatakan bahwa dengan penambahan pereaksi geser $\mathrm{NaOH} 2 \mathrm{M}$ dapat menunjukkan gugus hidroksil pada posisi 3,4'-OH pada cincin B dan bentuk $o$-diOH (orto-dihidroksi) yang terdapat pada struktur inti flavonoid. Berikut penafsiran kedudukan gugus hidroksil fenol bebas pada Gambar 1 penafsiran kedudukan gugus fenol spektrum $\mathrm{NaOH}$.

Pereaksi geser $\mathrm{AlCl}_{3} \quad 5 \quad \%$ yang ditambahkan menggeser posisi absorbansi maksimum pada isolat flavonoid sebesar 45 $\mathrm{nm}$, sedangkan kenaikan intensitas dari spektra yang terbentuk dikarenakan dalam isolat masih terdapat glukosa yang bisa menaikkan intensitas. Hal ini menunjukkan bahwa pada posisi 3' dan 4' terdapat gugus $o$-diOH (ortodihidroksi) yang membentuk komplek dengan Al yang bersifat labil dan penafsiran kedudukan gugus fenol spektrum $\mathrm{AlCl}_{3}$ pada Gambar 2

Penambahan pereaksi geser $\mathrm{CH}_{3} \mathrm{COONa}$ menyebabkan pergeseran sebesar $20 \mathrm{~nm}$. Pergeseran ini terjadi karena ionisasi pada gugus hidroksil flavonoid yang paling asam, yang pada senyawa flavonoid dimiliki oleh gugus $7-\mathrm{OH}$ dan adanya oksigenasi pada $\mathrm{C}_{6}$ atau $\mathrm{C}_{8 .}{ }^{[7]}$ Berikut penafsiran kedudukan gugus fenol spektrum $\mathrm{CH}_{3} \mathrm{COONa}$ pada Gambar 3

Penambahan $\quad \mathrm{CH}_{3} \mathrm{COONa} / \mathrm{H}_{3} \mathrm{BO}_{3}$ akan menjembatani kedua gugus hidroksil pada gugus $o$-diOH. Penambahan $\mathrm{CH}_{3} \mathrm{COONa} / \mathrm{H}_{3} \mathrm{BO}_{3}$ menyebabkan pergeseran ke kanan sebesar $15 \mathrm{~nm}$ yang mengarah pada substitusi posisi $o$-diOH pada cincin A $(6,7)$

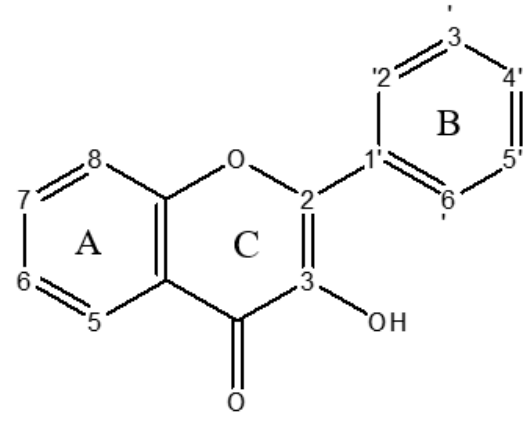<smiles>O=c1c(O)c(-c2cc[Z](O)c(O)c2)oc2c1C=[PH](O)(O)=[PH]2O</smiles>

Gambar 1 Penafsiran kedudukan gugus fenol spektrum $\mathrm{NaOH}$

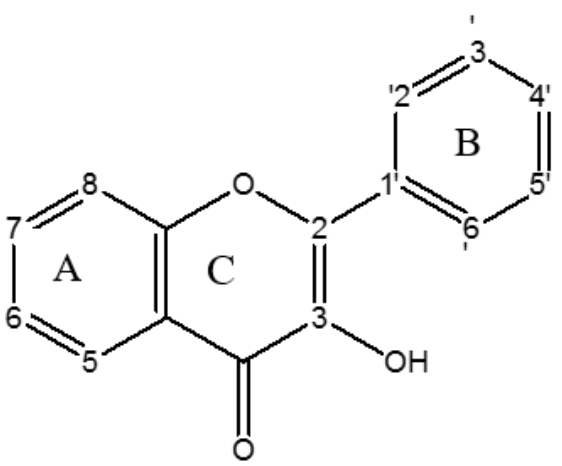<smiles>O=c1c(O)c(-c2cc[Z](O)c(O)c2)oc2cccc(O)c12</smiles>

Gambar 2 Penafsiran Kedudukan Gugus Fenol Spektrum $\mathrm{AlCl}_{3}$

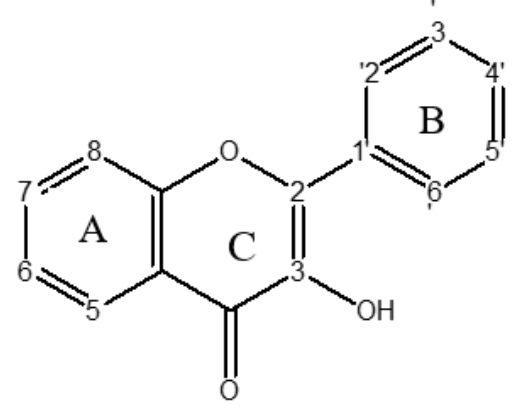<smiles>O=c1c(O)c(-c2ccccc2)oc2cc(O)ccc12</smiles>

Gambar 3 Penafsiran Kedudukan Gugus Fenol Spektrum $\mathrm{CH}_{3} \mathrm{COONa}$ 
atau $(7,8) \cdot{ }^{[7]}$ Hal ini dikarenakan terputusnya glukosa, sehingga membentuk transisi $n-\pi^{*}$. Dengan adanya transisi $\mathrm{n}-\pi^{*}$ maka membutuhkan energi yang kecil sehingga panjang gelombangnya semakin besar. Sedangkan penurunan intensitas disebabkan adanya glukosa yang terikat pada flavonoid sudah terhidrolisis oleh asam yaitu asam borat. Adapun penafsiran kedudukan gugus fenol spektrum $\mathrm{CH}_{3} \mathrm{COONa} / \mathrm{H}_{3} \mathrm{BO}_{3}$ adalah pada Gambar 4

Hasil spektrum inframerah (Gambar 5) dari hasil pemisahan KLTP menunjukkan bahwa isolat flavonoid mengandung gugus fungsi seperti rentangan asimetri $\mathrm{O}-\mathrm{H}$ dari gugus alkohol yang terikat pada gugus alifatik dan aromatik. Puncak serapan sangat lebar terbentuk pada bilangan gelombang $3443,9 \mathrm{~cm}^{-}$ ${ }^{1}$, sebagai akibat dari vibrasi ikatan hidrogen intramolekul. ${ }^{[10]}$ Pelarut yang digunakan adalah aseton : air yang bersifat sangat polar yang mempengaruhi serapan-serapan O-H. Karena dimungkinkan gugus $\mathrm{O}-\mathrm{H}$ yang terbaca pada spektrum IR dari gugus pelarut (aseton : air) sehingga pada bilangan gelombang 3500-3000 $\mathrm{cm}^{-1}$ terbentuk serapan $\mathrm{O}-\mathrm{H}$ yang sangat melebar. Adanya ikatan hidrogen di dalam molekul menyebabkan bergesernya pita serapan ke bilangan gelombang yang lebih rendah.

Bilangan gelombang 1367,9 $\mathrm{cm}^{-1}$ menunjukkan puncak serapan cincin aromatik. Pada spektrum ini terlihat adanya pita serapan kuat karbonil pada angka 1648,3 $\mathrm{cm}^{-1}$, dimungkinkan merupakan karakteristik senyawa flavonoid. Senyawa karbonil disini adalah golongan eter yang diperkuat oleh puncak serapan $1060,3 \mathrm{~cm}^{-1}$ yang menunjukkan

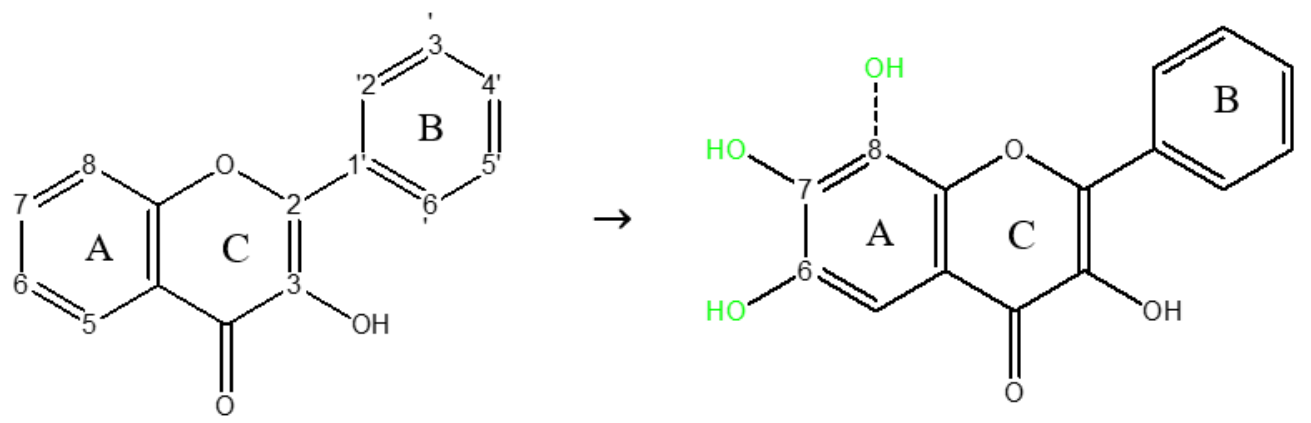

Gambar 4 Penafsiran Kedudukan Gugus Fenol Spektrum $\mathrm{CH}_{3} \mathrm{COONa} / \mathrm{H}_{3} \mathrm{BO}_{3}$

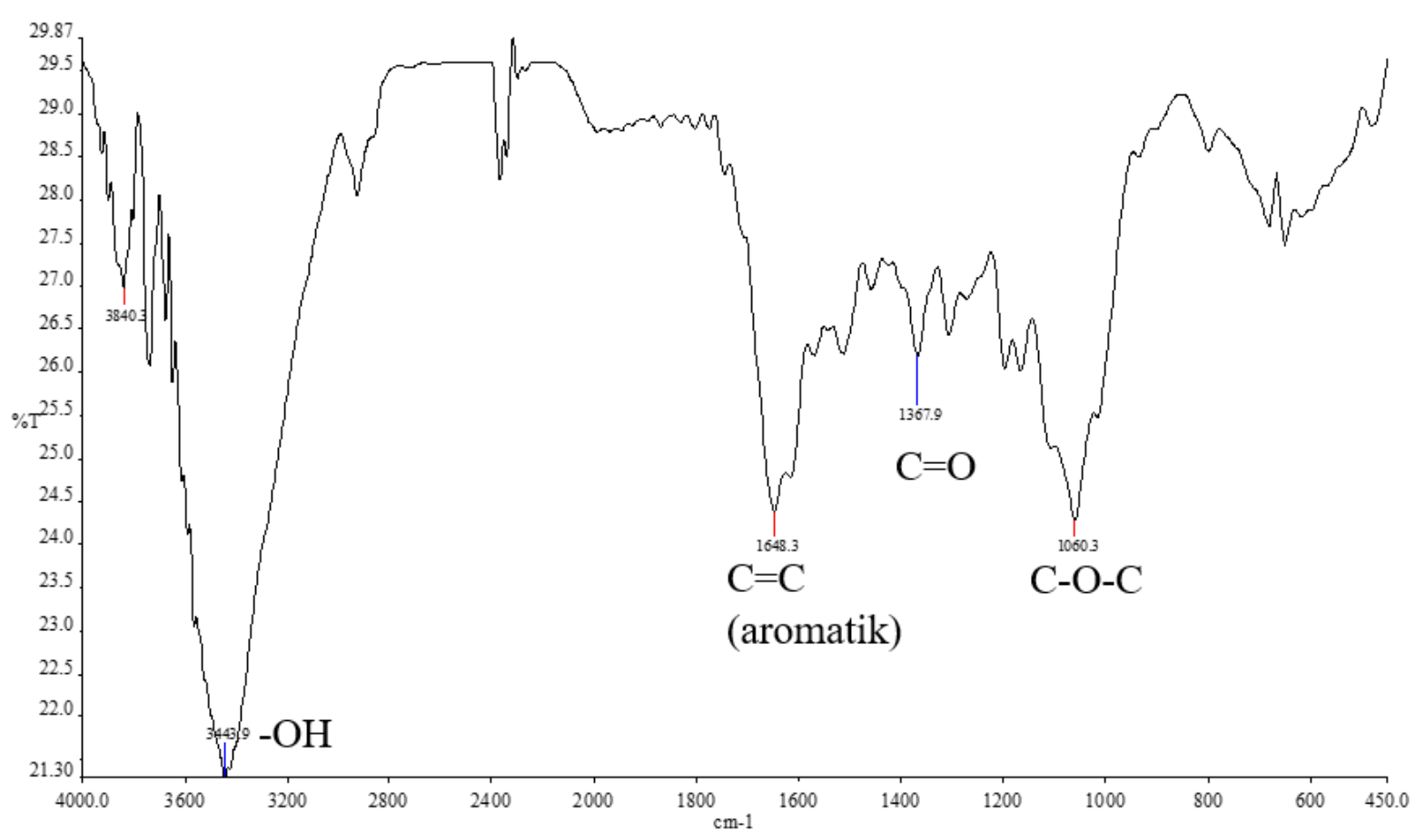

Gambar 5 Penafsiran Spektrum FTIR dari isolat flavonoid. 
<smiles>O=c1c(O)c(-c2ccc(O)c(O)c2)oc2c(O)c(O)cc(O)c12</smiles>

\section{$5,7,8,3^{\prime}, 4^{\prime}$-pentahidroksiflavonol}<smiles>O=c1c(O)c(-c2ccc(O)c(O)c2)oc2cc(O)c(O)c(O)c12</smiles>

$5,6,7,3^{\prime}, 4^{\prime}$-pentahidroksiflavonol

Gambar 6 Senyawa flavonoid yang ada dalam daun kembang bulan

adanya C-O-C. Maka berdasarkan identifikasi puncak-puncak spesifik tersebut merupakan puncak spesifik dari senyawa flavonoid, sehingga memperkuat dugaan bahwa dalam isolat hasil pemisahan dengan KLT mengandung senyawa flavonoid. Dari hasil identifikasi senyawa flavonoid dengan spektrofotometer UV-Vis dan FTIR dapat diduga bahwa senyawa flavonoid yang ada dalam daun kembang bulan yaitu $5,7,8$, 3',4'pentahidroksiflavonol atau 5,6,7,3',4' pentahidroksiflavonol (Gambar 6).

\section{Kesimpulan}

Dari hasil penelitian dan pembahasan pada penelitian ini maka dapat disimpulkan adalah sebagai berikut : Eluen terbaik untuk pemisahan senyawa flavonoid dari daun kembang bulan adalah eluen $n$ - heksana : etil asetat (8:2); Senyawa flavonoid yang diperoleh dari hasil pemisahan ekstrak daun kembang bulan dengan kromatografi lapis tipis adalah $5,7,8,3^{\prime}, 4^{\prime}$ '-pentahidroksiflavonol atau 5,6,7,3',4'-pentahidroksiflavonol.

\section{Referensi}

[1]. Puspitasari Firsoni, L. dan Andini, L. 2011. Efek Daun paitan (Tithonia diversifolia (Hemsley) A. Gray) dan Kelor (Moringa oleifera, Lamk) Di Dalam Pakan Komplit InVitro.

[2]. Pratiwi Sari, R. 2014. Daya Larut Fraksi nbutanol Daun Kembang Bulan terhadap Batu
Ginjal Kalsium secara In- vitro. Banjarmasin: Media Sains Volume 7 Nomor 2.

[3]. Siregar, R. 2011. Uji Aktivitas Antibakteri Ekstrak Etanol Daun Kembang Bulan (Tithonia diversifolia (Hemsley) A. Gray) terhadap bakteri Staphylococcus aureus, Propionibacterium acnes dan Pseudomonas aeruginosa. Skripsi Departemen Farmasi FMIPA USU. Medan.

[4]. Widari, M. 2005. Isolasi Senyawa Flavonoid dari Daun Kembang Bulan (Tithonia diversifolia (Hemsley) A. Gray). Skripsi Departemen Farmasi FMIPA USU. Medan

[5]. Harborne, J.B. 1984. Metode Fitokimia Penuntun Cara Modern Menganalisa Tumbuhan. Diterjemahkan oleh Kosasih Padmawinata dan Iwang Soediro. Bandung : Penerbit ITB.

[6]. Harborne, J.B. 1987. Metode Fitokimia Penuntun Cara Modern Menganalisis Tumbuhan. Bandung: ITB.

[7]. Markham, R.K. 1988. Cara Mengidentifikasi Flavonoid. Bandung : Penerbit ITB.

[8]. Rahimah, dkk. 2013. Karakterisasi Senyawa Flavonoid Hasil Isolat dari Fraksi Etil Asetat Daun Matoa ( Pometia pinnata J.R. Forst\& G.Forst).

[9]. Sastrohamidjojo, H. 2007.Spektroskopi. Yogyakarta : Liberty Yogyakarta.

[10]. Harvey, D. 2000. Modern Analytical Chemistry. United States of America: The McGraw-Hill Companies, Inc. 